\title{
Plant foods, stone tools and food preparation in prehistoric Europe: An integrative approach in the context of ERC funded project PLANTCULT
}

\author{
Soultana Maria Valamoti ${ }^{1}$, Danai Chondrou ${ }^{1}$, Tasos Bekiaris ${ }^{1}$, Ismini Ninou ${ }^{1}$, \\ Natalia Alonso ${ }^{2}$, Maria Bofill ${ }^{1}$, Maria Ivanova ${ }^{3}$, Sofia Laparidou ${ }^{1}$, \\ Calla McNamee ${ }^{4}$, Antoni Palomo ${ }^{5}$, Lambrini Papadopoulou ${ }^{6}$, Georgina Prats ${ }^{1}$, \\ Hara Procopiou ${ }^{7}$, Georgia Tsartsidou ${ }^{8}$
}

1. LIRA Laboratory, Department of Archaeology, School of History and Archaeology, Aristotle University of Thessaloniki, 54124 Thessaloniki, Greece \& Center for Interdisciplinary Research and Innovation

(CIRI-AUTH), Balkan Center, Buildings A \& B, Thessaloniki, 10th km

Thessaloniki-Thermi Rd, P.O. Box 8318, 57001. Email: Valamoti: sval@hist.auth.gr;

Chondrou: dachondr@hist.auth.gr; Bekiaris: anasbek@hist.auth.gr; Ninou: isminininou@hist.auth.gr;

Bofill: marbof@hist.auth.gr; Laparidou: laparids@hist.auth.gr; Prats: gprats@hist.auth.gr

2. GIP, Departament d'Història, Fac. de Lletres, INDEST (HAR2016-78277-R), Universitat de Lleida, Pl. Víctor Siurana, 1, 25003, Lleida, Catalonia, Spain. Email: nalonso@historia.udl.cat

3. Institut für Ur-und Frühgeschichte und Vorderasiatische Archäologie, Universität Heidelberg, Sandgasse 7, 69117, Heidelberg, Germany. Email: ivanova@uni-heidelberg.de

4. The Malcolm H. Wiener Laboratory for Archaeological Science, The American School of Classical Studies at

Athens, 54 Souidias Street, 106 76, Athens, Greece. Email: callamcnamee@gmail.com

5. Museu d' Arqueologia de Catalunya, Curator of prehistory collections, ACdPC, Dpt. de Cultura, Generalitat de Catalunya, Passeig de Santa Madrona 39-41, 080838, Barcelona, Spain.

Email: Palomo: antoni.palomo@gencat.cat

6. Department of Geology, Aristotle University of Thessaloniki, 54124 Thessaloniki, Greece.

Email: Papadopoulou: lambrini@geo.auth.gr

7. Department of Archaeology, University of Paris I, Panthéon-Sorbonne, Centre Michelet, 318, 3 rue Michelet 75006 Paris, France. Email: Haris.Procopiou@univ-paris1.fr

8. Ephorate of Palaeoanthropology-Speleology, Ardittou 34 B, 11636, Athens, Greece.

Email: gtsartsidou@ymail.com

\begin{abstract}
:
The transformation of food ingredients into meals corresponds to complex choices resulting from the interplay of environmental and cultural factors: available ingredients, technologies of transformation, cultural perceptions of food, as well as taste and food taboos. Project PLANTCULT (ERC Consolidator Grant, GA 682529) aims to investigate prehistoric culinary cultures from the Aegean to Central Europe by focusing on plant foods and associated food preparation technologies spanning the Neolithic through to the Iron Age. Our paper offers an overview of the lines of investigation pursued within the project to address plant food preparation and related stone tool technologies. The wide range of plant foods from the area under investigation (ground cereals, breads, beer, pressed grapes, split pulses, etc.) suggests great variability of culinary preparations. Yet, little is
\end{abstract}

Published by the School of History, Classics and Archaeology, University of Edinburgh ISSN: 2055-0472. URL: http://journals.ed.ac.uk/lithicstudies/

Except where otherwise noted, this work is licensed under a CC BY 4.0 licence. 
known of the transformation technologies involved (e.g., pounding, grinding, and boiling). Changes in size and shape of grinding stones over time have been associated with efficiency of grinding, specific culinary practices and socioeconomic organisation. Informed by ethnography and experimental data, as well as ancient texts, PLANTCULT integrates archaeobotanical food remains and associated equipment to address these issues. We utilize a multifaceted approach including the study of both published archaeological data and original assemblages from key sites. We aim to develop methods for understanding the interaction of tool type, use-wear formation and associated plant micro- and macro- remains in the archaeological record. Our experimental program aims to generate (a) reference material for the identification of plant processing in the archaeological record and (b) ingredients for the preparation of experimental plant foods, which hold a key role to unlocking the recipes of prehistory. Plant processing technologies are thus investigated across space and through time, in an attempt to explore the dynamic role of culinary transformation of plant ingredients into shaping social and cultural identities in prehistoric Europe.

Keywords: food identities; plant food processing; prehistoric grinding and pounding tools

\section{Grinding technologies and the culinary transformation of plant foods: The PLANTCULT approach}

Plant foods have been essential for human subsistence since prehistoric times. Moreover, in the last decade, increasing evidence highlights the significance of plant foods for Palaeolithic hunter-gatherers. Recent research on dental calculus from Palaeolithic and Natufian populations has revealed the consumption of plants as food as well as for medicinal purposes (Hardy et al. 2012; Power et al. 2016). Processing of edible plant parts such as seeds, fruits, roots etc. facilitates nutrient intake by the human digestive system (KanfaniZahar 1994:204-210; Stahl 1984; 1989; Yen 1989; see also Capparelli et al. 2011 for an overview of the state of the art in terms of plant ingredients). Evidence for such processing (i.e. starch grains and related use-wear) was identified on grinding and pounding implements from several Palaeolithic sites (e.g., Middle and Upper Palaeolithic sites of Bilancino II, Italy and Pavlov VI, Czech Republic, as well as Epipalaeolithic Ohalo II, Israel, Dubreuil \& Nadel 2015; Revedin et al. 2010) suggesting the application of plant processing practices by early hunter-gatherers. The presence of pounding and grinding tools increased among Natufian and Neolithic farming communities, often being associated with plant processing for food production. The ratio between grinding and pounding implements has even been used to assess the degree of sedentism and dependency on agricultural crops (Dubreuil 2008; Ebeling \& Rowan 2004; Kraybill 1977; Rowan \& Ebeling 2008; Wright 1991; 1994; 2014).

PLANTCULT (Valamoti et al. 2017) focuses on the plant food cultures of the prehistoric farming communities in a large part of Europe with a special emphasis on related stone tool grinding technologies. This project aspires to a diachronic study of culinary traditions and their change over time. Ingredients, related processing and cooking practices as well as associated equipment will be researched, in conjunction with an extensive experimental program, the study of ancient written sources, and the exploration of traditional practices in relation to plant food ingredients. The natural and cultural factors, manifested in the form of preferences, differences or changes, will be examined by focusing on their role in influencing dietary practices.

Rather than generalizing from a single region or archaeological site, our aim is to identify culinary cultures in a large geographical area, from the Aegean to Central Europe (Austria, southern Germany, Switzerland), and detect their evolution and change over a vast period of time, spanning from the 7th to the 1st millennium BCE. Different trajectories exist in the social development of this broad region, which has received influences from both the Eastern 
Mediterranean and Central Asia. Moreover, this time span allows us to explore changes in social and economic organisation from the Neolithic to the Bronze Age and later Iron Age periods, from the first farmers of the region to the first cities. Our aim is to understand the role of culinary practice and innovation in shaping these trajectories. The selected study area allows us to explore an East-West dynamic in a wider geographical scale.

Our multi-disciplinary approach combines methodologies of humanities and sciences in an attempt to explore culinary identities that are part of Europe's intangible cultural heritage. Plant foods may have constituted identity signifiers related, for example, to the origins of the first farmers: identity could have been constructed on the basis of ancestral cereal species brought along from the East, their cultivation and consumption used to signify these origins and through that build specific identity characteristics for the consumers of different cereal species; or, the consumption of specific plant food products may have been used as a means to signify Bronze Age elite identity, as is the case of alcohol for some communities but not necessarily all (confer Valamoti 2017). Regions of wine and beer consumption, for example, often exist in archaeological narratives, yet, such stereotypes and generalizations may be masking variability and a much richer mosaic generated by the diversity of human choice (e.g., Valamoti 2018). PLANTCULT focuses, in a more nuanced way, on the role of culinary traditions and innovations into shaping the social landscape over long time periods, in some cases culminating in hierarchical societies. Taking alcoholic drinks for example, our ongoing research clearly shows that wine was not consumed everywhere during the Bronze Age as there are indications for brewing beer too, and it is not an obligatory condition for the emergence of elites in the Aegean: alternative processes and trajectories in the manipulation of specific plant food products were underway and we aim to further investigate this potential of plant foods (Valamoti 2017; 2018). The project aims to reach a new understanding by developing a novel, rigorous methodology for the study of plant food remains and culinary practices in prehistoric Europe, through the integration of end products (food) and associated equipment. The new multidisciplinary methodologies and integrative approaches that will be developed by the PLANTCULT team will be applicable not only to the assemblages studied by the project, but others as well (Valamoti et al. 2017).

The main research question of the project concerns the way plant-related cuisine shaped and modified cultural identities in prehistoric European societies over time. The project will examine an impressive body of actual food remains and, building upon earlier pilot studies, will generate a solid methodological tool for ancient plant food identification. Moreover, by assembling evidence from plant food processing stone tools, cooking facilities, and cooking pottery, the project will address variability and change of food preparation technologies, parameters closely related to culinary identities and socioeconomic relationships.

A database of plant food ingredients, actual plant foods, as corresponding to snapshots of prehistoric cooked foods, equipment and archaeological context will form the basis for mapping culinary signatures in the study area and their evolution through time. This information will then be examined within the wider narratives of cultural identities and social change among prehistoric communities of the study area. Different plant food species or different plant food recipes may have been introduced at different times in the study area; millet for example appears in the 2nd millennium BCE and evidence for brewing beer is available for the end of the 3rd millennium BCE (Valamoti 2018). The interdisciplinary approach adopted by the project whereby archaeobotanical data are associated to plant food processing equipment will allow a better understanding of culinary transformations and innovations, but also of the interplay between available ingredients and cooking technologies.

To achieve the project's ambitious goal, a series of databases have been designed to record prehistoric grinding tools, cooking pots and cooking installations, and, also, ancient texts related to specific plant foods, often encountered in the archaeobotanical record, 
including recipes. Databases will also be generated for use-wear patterns, starch and phytolith deformations or alterations caused by grinding, fermenting and cooking. All these will then be connected in order to ask complex questions with many variables, in order to identify change across space and through time.

\section{Exploring cultural diversity in grinding technologies of ancient Europe}

In the wider context of PLANTCULT, grinding and pounding stone tools (e.g., querns and handstones, mortars and pestles) are of special significance. They represent vital technological products for the processing of plantfoods, along with other implements made of wood that are usually not preserved in the archaeological record. Grinding has serious advantages in plant food preparation as it crushes plant ingredients into smaller particles thus reducing cooking time, facilitating fermentation processes and nutrient absorption during digestion (Capparelli et al. 2011; Kanfani-Zanhar 1994: 204-210; Stahl 1989; see for example Valamoti 2011 for an overview on cereals). The shape, form, size and raw materials of these tools are, to a certain extent, determined by regional availability, as well as an interplay of cultural and personal choices. Our approach to grinding and pounding stone tools is manifold. We integrate archaeological, experimental and ethnographic evidence in order to investigate the technological variety of these tools detected in the archaeological archive, in direct association with the dietary cultures of the past. Our research questions concern all stages of the tool life cycle -from the selection of the raw material, to the final disuse and deposition of the artifact- since it is through them that objects incorporate various values and meanings and shape their social and cultural entity (Hodder 2012: 40-112; Hoskins 1998: 183-198; 2006; Gosden \& Marshall 1999; Kopytoff 1986). These stages are briefly discussed below.

The raw material properties (hardness or resistance to friction, natural roughness, cohesion of the stone etc.), for instance, are directly associated with the efficiency of the tool for grinding and pounding activities (Delgado-Raack et al. 2009; Shoumacker 1993; Schneider 2002: 40-50). Yet, a number of other factors may affect the procurement strategies, such as environmental (e.g., raw material availability stress, topography of specific environment and accessibility of sources), economic (e.g., quality and degree of workability of the available raw materials) and finally, often elusive cultural and social factors (e.g., stone working traditions, aesthetic and symbolic values, participation in social networks). Moreover, different rock variations may have been used for the preparation of different foodstuffs (e.g., Adams 1999: 479-480), such as foods in powder form, like flour, or coarsegrained meals like "groat" or bulgur. Thus, the raw material choices for the manufacture of grinding and pounding stone tools and the degree of detectable variation could be relevant to the technical choices associated with the desired and envisaged meal.

Morphometric variation is equally important. It can inform us on the existence of various modes of raw material selection (i.e. the initial form of the rock extracted from quarries or collected from primary and secondary deposits), reduction strategies, and tool manufacture. Metric attributes (i.e. tool measurements, workface size) have been also correlated with tool efficiency and in some cases have been used to make inferences regarding function (i.e. their association with food processing, particularly that of cereal confer Mildwaters \& Clarkson 2018; Runnels 1981: 250-251; Schön \& Holter 1990; Stroulia 2010: 37-39, 48-50). Ethnography offers examples of metric attributes directly associated with tool functions (e.g., Roux 1985: 34-48). Yet there is no universal rule (e.g., Gast 1968: 347-350). Moreover, a correlation may exist between the metric and morphological attributes and the exploited raw material sources (i.e. the form of the available nodules). Mapping the metric variation of grinding tools across space and time can reveal valuable information. For example, it has been suggested that there has been an increase in the size of milling tools in Greece from the 
Neolithic to the Bronze Age and beyond (Runnels 1981: 154). However, a more extensive overview of archaeological data reveals greater complexity than the simple size/time equation implies (see Valamoti et al. 2013 for a relevant discussion).

Morphological variations among grinding tools, especially regarding the configuration of their workfaces, have significant functional implications. They can suggest specific tool types (i.e. the morphology of the implement that moves on the workface), kinematics (i.e. rotary or reciprocal movement) and body postures (i.e. sitting, kneeling or standing position) employed during use (e.g., Moritz 1958: 31-32; Nierlé 1983; 2008; Zimmermann 1988; de Beaune 1989; Procopiou 1998: 185-186; Adams 1999; Delgado-Raack 2008: 292-347; Stroulia et al. 2017). The use of one tool type instead of another can be a matter of functional differentiation (e.g., different products processed) or cultural manifestation, as has been clearly supported by various studies (see for example, Hamon 2008; Hamon \& De Gall 2013). Technomorphological changes over a large area and time span are therefore important to detect and explore in order to investigate their cultural and socioeconomic context.

Another important question pertains to the range of functions grinding tools may have had and whether these represent specialized tool-types were intended for the processing of specific plant species or multifunctional implements used for a variety of plant (or maybe animal as well) foods or other substances. The latter, for example, has been suggested by some researchers for Greek Neolithic grinding tools (Runnels 1981: 152-153; Stroulia 2010: 48-51; Tsoraki 2008: 92-100). On the other hand, the rich ethnographic record provides diverse indications underlining the complexity of human choices (e.g., Roux 1985 for specialized implements from Tichitt, Mavritania, and Kraybill 1977; McCarthy 1941; 1976: 75 for multipurpose tools in the Aboriginal lithic technologies of Australia).

As regards the arrangement of foodprocessing activities in space, archaeology and ethnography reveal an equally complex picture (e.g., David 1998; Hamon \& LeGall 2013; Naveh 1996; Nixon-Darcus 2014: 196-204; Roux 1985: 46; Wright 2000). We intend to explore this variation and its social significance in depth, by fully mapping the spatial layout of food-processing tasks.

Moreover, it has been attested ethnographically that grinding tools often have a very long life span extending for several decades and are therefore considered to be of great value (e.g., Horsfall 1987; Searcy 2011: 72-74). One would expect high levels of curation to ensure their longevity, especially in cases where the raw material sources are not easily accessible. However, the archaeological archive does not always support this generalized economical approach (e.g., fully functional tools were used as construction material, disposed of or deposited in pits, ditches or other intriguing contexts, sometimes after being deliberately decommissioned, Akkermans et al. 2012; Adams 2008; Rosenberg 2013; Stroulia \& Chondrou 2013; Molloy et al. 2014).

Finally, grinding and pounding tools may have complex biographies, with episodes of use, re-use and recycling, with their functions often extending way beyond their primary use. The type of manipulation these tools receive, in the context of their initial function and beyond, can offer important insights into the socioeconomic and cultural values and meanings they convey. Within PLANTCULT, numerous key sites have been selected for their excellent contextual information regarding spatial arrangement, preservation of plant food remains as well as grinding and cooking equipment (Valamoti et al. 2017). Other sites of special interest for their grinding technologies are also being considered (Figure 1). 


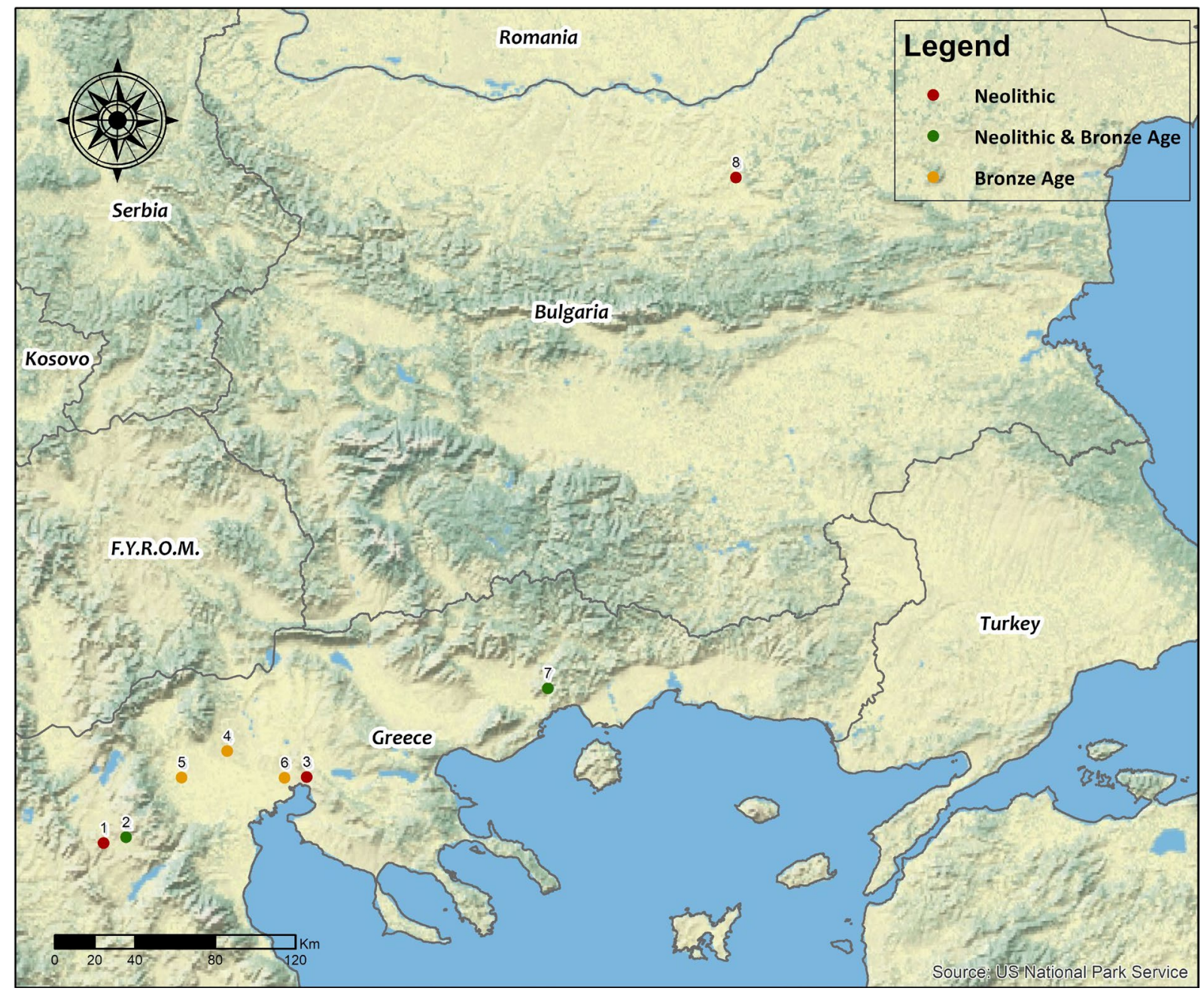

Figure 1. Sites with grinding and pounding stone tool assemblages under study in the context of Plantcult ERC project. (1) Fillotsairi-Mavropigi, (2) Kleitos, (3) Stavroupoli, (4) Archontiko, (5) Aggelochori, (6) Agios Athanasios, (7) Dikili Tash, (8) Petko Karavelovo (ERC PLANTCULT). Source: US National Park Service.

\section{Grinding tools and plant foods: The PLANTCULT approach}

\subsection{General issues}

Grinding and pounding stone tools, an important part of prehistoric technology, remained in use for millennia, in some cases with only small changes in morphology and general ways of use. However, contrary to what was once believed, although resilient to change, these tool types do not constitute monolithic toolkits, but present variations that, no matter how subtle, are significant and thus worth exploring.

Also, contrary to established perceptions of the past that have associated these tools exclusively with the processing of plants, it is now widely accepted that grinding and pounding stone tools were used for treating a wide range of substances, organic and inorganic (Adams 1999; Del Pilar Babot \& Apella 2003; Gould 1968; Kraybill 1977; Schroth 1996; Wright 1994).

The research goals of PLANTCULT will be complemented by an experimental program regarding the manufacture of grinding tools of various sizes and raw materials and their use for the processing of a variety of plant species recorded in the archaeological archive. Our approach towards plant foods and associated grinding technologies consists of the following lines of investigation. 


\subsection{Tools}

Our study integrates systematic bibliographic research and the study of grinding tool assemblages from selected key sites that have yielded plant foods and grinding tools in well preserved contexts related to food preparation. More specifically, we intend to archive all published evidence on grinding tools in the PLANTCULT study area. An actual problem confronting all researchers of food processing stone tools is the insufficient and unsystematic publication of grinding and pounding stone tools and the scarcity of holistic approaches on their production, use and manipulation. The PLANTCULT study area (the Aegean, the Balkans and Central Europe) has attracted international scientific interest on prehistoric economy and subsistence strategies. One of the aims of the bibliographic archive is the collection and organisation of the scattered archaeological information concerning prehistoric food processing tools, in order to create an essential guide of the relevant toolkits and techniques in the area. This database will render extensive comparisons possible, offering insight into potential spatiotemporal patterns. When completed, the database will be accessible through the project's website (www.plantcult.web.auth.gr).

The assemblages from key sites will be analysed at a macroscopic and a microscopic level (e.g., Figure 2).
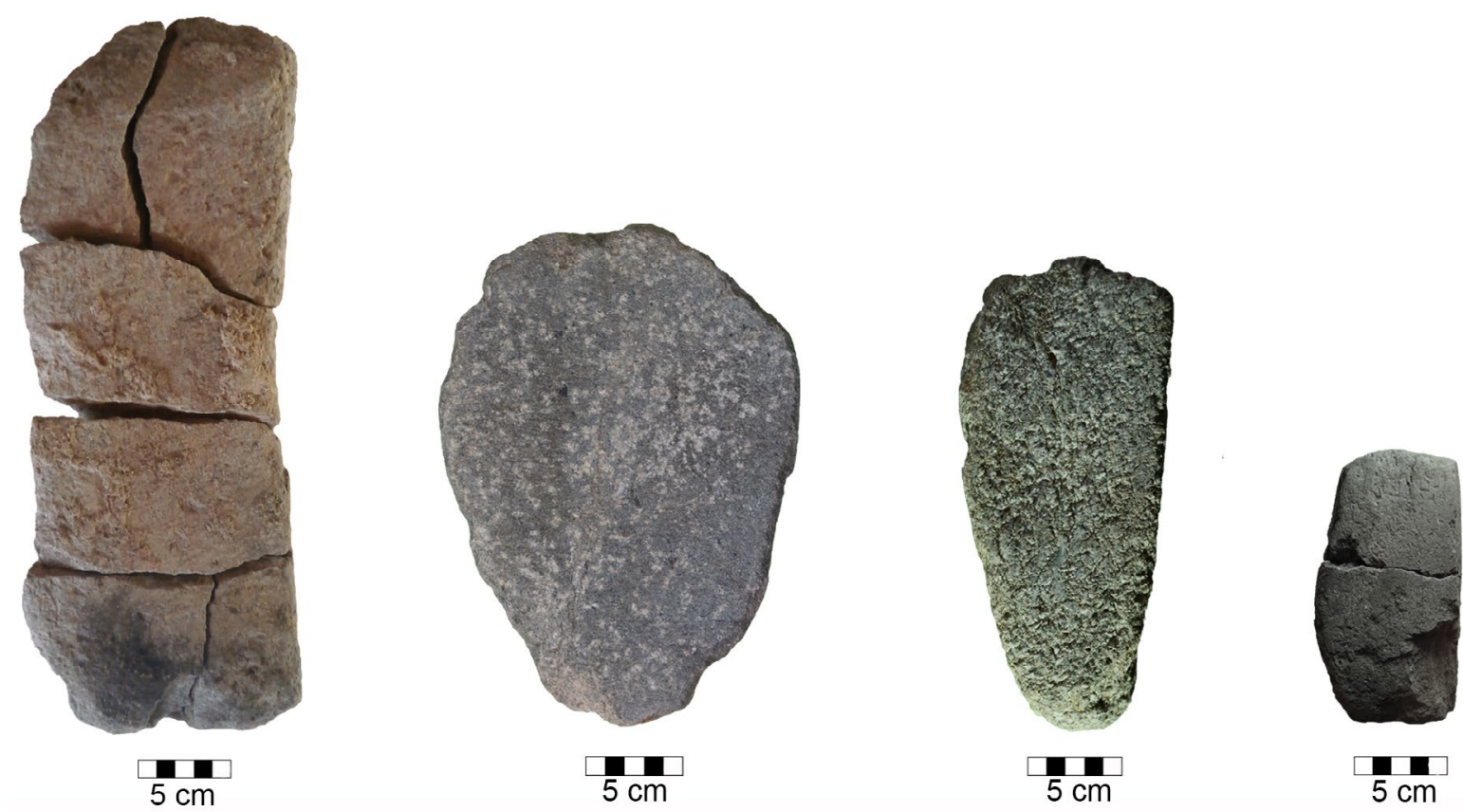

Figure 2. Grinding implements from various assemblages under study (ERC PLANTCULT).

The macroscopic analysis focuses on the following parameters:

The macroscopic analysis focuses on the following parameters:

a) Preservation (number and types of breakages and other types of wear e.g. effects of fire, weathering)

b) Raw material (type of material, the form in which it is exploited -e.g. river-pebbles, boulders, eroded and naturally detached material, or quarried pieces of stone- and its physical attributes with emphasis on the variability existing within the same lithological groups),

c) Tool morphology,

d) Metrics (size and weight, particularly important in the case of handstones)

e) Typology (tool types and subtypes) 
f) Manufacturing techniques and curation (techniques employed in the shaping and maintenance of a tool, their sequence and extent of application)

g) Aspects of use (kinematics, type, distribution and degree of use-wear). The macroscopic view will serve as a first step complemented later by microscopic analysis.

h) Excavation data that provide important contextual information.

All the features recorded in the PLANTCULT's ancient grinding tools database are necessary in order to understand the role of food grinding implements in a prehistoric site. We are ultimately interested in the role of food processing tools in the economic and social organisation of the settlement. Through establishing the whole sequence from raw material procurement (when aspects of raw material provenance and selection strategies are available) to the production and use of stone tools, and understanding food preparation in the wider context of daily life and special occasions, we will examine the possible meaning of the tools for each group and the notions and mentalities towards food. The comparative study of all the characteristics of the selected prehistoric assemblages can lead to a better understanding of site formation, socioeconomic organisation and changes through time. For example, Nelson \& Lippmeier (1993), in their study on prehistoric sites in the American southwest, work on the hypothesis that the ways a site is formed and the land is used may be reflected on the technomorphological features and the use of food grinding implements. The general characteristics of the assemblages from permanent settlements (quality of raw materials, quality of manufacture, size, intensity of use etc.) were distinctively different from the corresponding qualities of tools found in seasonal camps. In this way, the tool assemblages are indicative of site formation patterns (for other examples of the potential of the comparative studies of the general macroscopic features of food processing tools: AbadiReiss \& Schneider 2010; Wright 2000; 2014).

\subsection{Functional analysis of grinding stone tools}

The next step is the microscopic analysis of use-wear, based on the detailed description of the characteristics of the workfaces of the tools. Regarding grinding tools, the interaction of two contacting surfaces together with an intermediary substance generates distinctive and identifiable use-wear patterns (confer Adams 1989; Adams et al. 2009; Bofill 2012; Bofill et al. 2013; Delgado-Raack 2008: 140-184; Dubreuil 2002: 115-207; 2004; Hamon 2006: 64-65; 2008; Hayes et al. 2017; Procopiou 1998: 183-191; 2004).

Multiple scales of analysis will be applied. First, the general topography of the grinding surfaces will be macroscopically recorded in order to describe the distribution of manufacture and use-wear traces (with the aid of macro-photography and technical drawings). The second level of observation is focused on the description of use-wear traces, especially the surface microtopography, with the aid of a stereomicroscope with magnifications up to 100x (Figure 3 ). The third level of analysis employs different techniques and higher magnification scales. Because of the large size of grinding stones, rather difficult to observe under conventional microscopic devices, silicon casts will be taken from various parts of the tools' grinding surfaces and will be analysed at the École Centrale de Lyon, in collaboration with the Laboratoire de Tribologie et Dynamique des Systèmes (LTDS, UMR-5513). The use of a metallographic microscope and different 3D microscopic devices (i.e. confocal microscope, interferometer) will allow us to combine qualitative and quantitative data in the tools' functional analysis. 

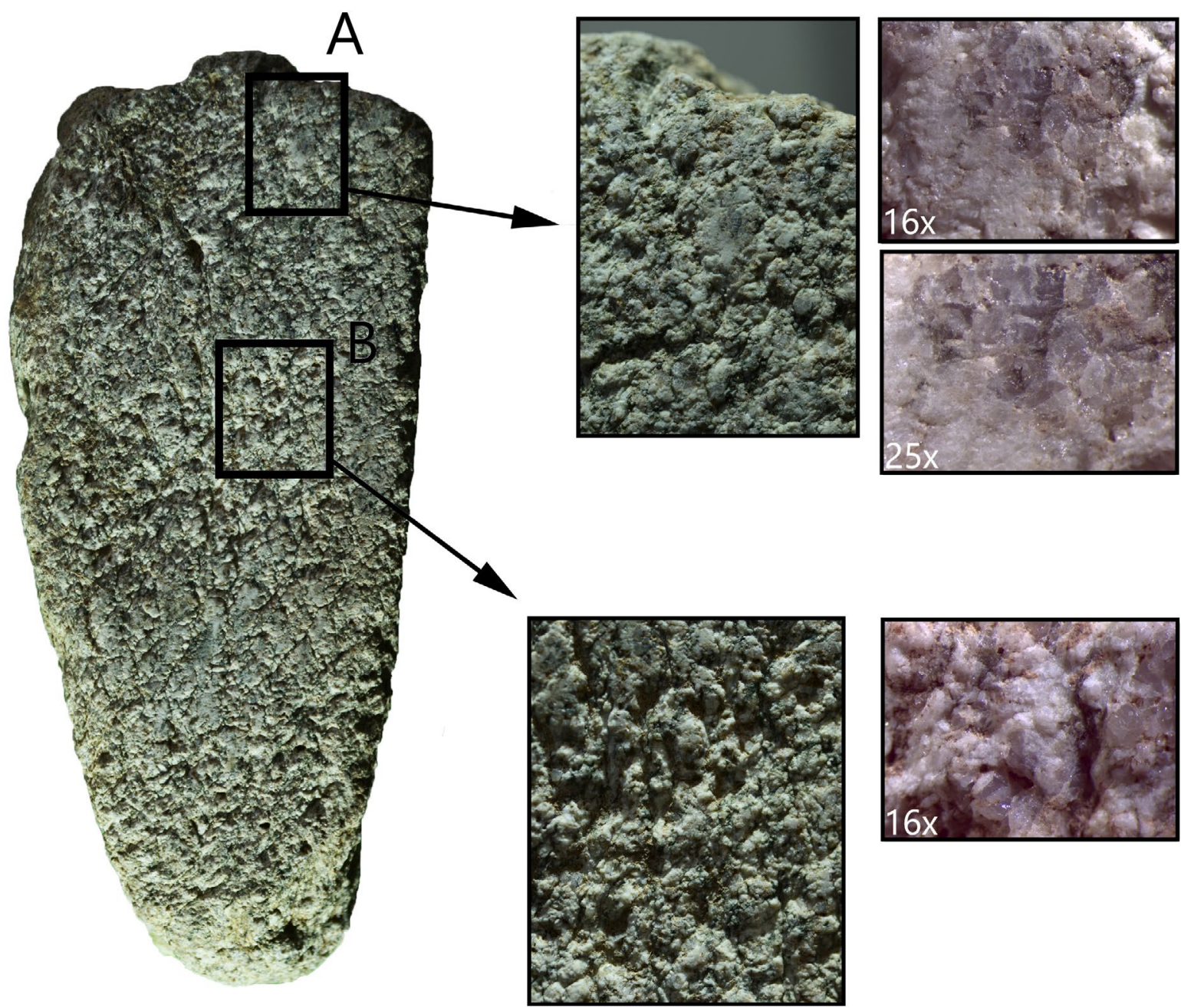

Figure 3. Use-wear analysis with the aid of a stereomicroscope: an example from the archaeological material. Macroscopic and microscopic details from a gneiss handstone from the Neolithic settlement of Stavroupoli exhibiting signs of abrasion as a result from grinding activities (A) but also percussive wear (B), in the form of an irregular concentration of deep cavities, "cutting" into the levelled, smooth and polished plateaus, as a result of the tool's reuse as an anvil (ERC PLANTCULT).

\subsection{Ethnographic database}

Ethnographic observations on the manufacture of grinding tools and the various social and economic aspects involved in their use and life histories can contribute towards a better understanding of ancient grinding technologies (e.g., Hamon \& Le Gall 2013; Procopiou 2003; Roux 1985: 65-77). Therefore, in the context of the project, a database has been designed in order to map different grinding equipment and associated traditions in different parts of the world. It will help us understand grinding technologies in real life situations and use this wealth of information to enhance our archaeological interpretations.

The goal of this database is twofold: (1) generate an exhaustive archive about the processes of plant grinding with stone tools in different parts of the world and (2) connect this information to specific archaeological, textual and experimental data related to plant grinding, in particular in association to food preparation. The database is structured in various sections (Figure 4) in order to systematically extract all relevant information from a wide range of publications that discuss or mention grinding tools in the present or recent past around the world. The publications taken into account comprise all ethnographic, ethnoarchaeological 
and archaeological documents where information about milling can be found. The most relevant to the project's objectives data are found in ethnoarchaeological publications. Ethnohistoric records are essential for developing models for the past, while archaeological papers are also included in our research, because there is a remarkable number of archaeological studies referring to ethnographic mills and milling processes for comparative purposes.

\begin{tabular}{|c|c|c|c|c|c|c|c|}
\hline PLANTCULT & Database Management & Home & Manage Data & Manage Lists & About & Contact & Hello, WEB-SR \\
\hline Plant & \multicolumn{7}{|c|}{ Ethnogrinding Database } \\
\hline Publications & Products & & Processes & Tools & Use & Quarrie & 3. manufacture \\
\hline
\end{tabular}

\section{COLLECTING OF BASIC AND GENERAL DATA IN EACH PUBLICATION}

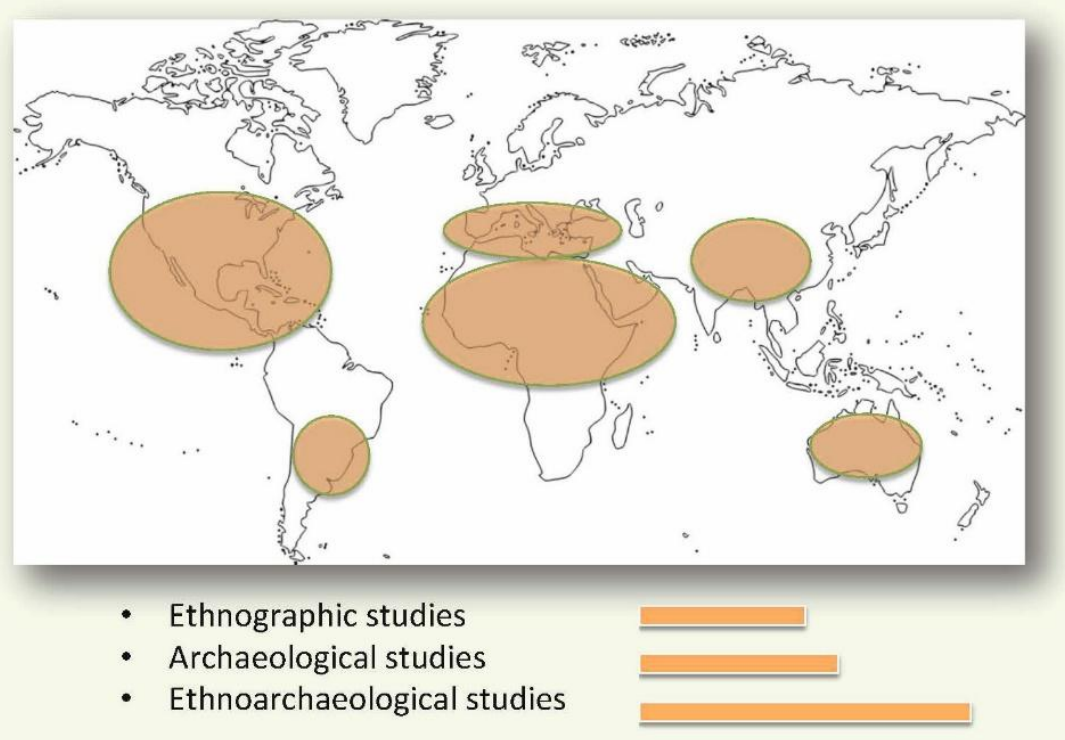

Figure 4. A screenshot from the Ethnogrinding Database (credits: ERC PLANTCULT).

The full range of activities from tool manufacture to the end products is recorded. It is organised in seven tabs: Publications, Plants, Products, Processes, Tools, Use, Quarries and Manufacture. One of the basic sections of this ethnographic database is the one dedicated to the tools, mainly querns and handstones, as well as other tools taking part in this process (mortars, pestles, percussion tools for the pecking of the grinding surface and sieves). The data have been organised into two parts: initial properties (raw material, dimensions and general morphology) and modified properties (modified by use: characteristics of the grinding surface and information about the duration of the use of the quern). Some information about the last stages of the use-life of the querns is also recorded: breakage, obsolescence patterns, discard, and abandonment. Several aspects of use and the social context of the "milling event" are recorded in the Use section: position of the quern, collecting devices, grinder posture, location in the house, number of querns in a household. Other aspects related to the grinders and their work (gender, age, social condition, frequency of milling, sociability etc.) are also recorded (Alonso et al. 2020). 


\subsection{Experimental tool study}

Experimentation in grinding technology was initially subscribed to the archaeological study of agricultural practices and the productivity of different tool types (e.g., Meurers-Balke \& Lüning 1992). Subsequently, functional studies concerning neolithic and protohistoric grinding stone industries in specific study areas have implemented complex experimental programs (in the Near East - Bofill 2015: 155-158, 197-218; Dubreuil 2002: 115-230; Central Europe - Hamon 2006: 74-102; Greece - Procopiou 1998: 183-191; Valamoti et al. 2013 and the South-west of the Iberian Peninsula - Delgado-Raack 2008: 140-226; Mensasanch et al. 2002; among others, see references in Dubreuil et al. 2015: table 7.2). Basic research goals for most of these experimental programs were the investigation of the effectiveness of grinding tools and the identification of diagnostic use-wear patterns generated on grinding surfaces. The PLANTCULT grinding experiments aim to broaden this perspective to include the technical and social factors that affected grinding technologies in prehistoric Europe, with a special link to the ground products.

The focus on plant food remains is a new and powerful line of research in experimental studies of grinding technology. The milling process is mediatized by the characteristics of the grains and substances to be processed (size, morphology, mechanical properties, chemistry), the tools' capacities (raw material properties, tools' morphometrics, technological features, etc.), and the desired final food product (all kinds of bread, pasta, semolina, etc.). The taste and the texture of food, crucial aspects in cuisine, are related to the processing techniques to which the ingredients are subjected during their preparation. From the pre-treatment of plant ingredients (drying, roasting, soaking, boiling, etc.) to the final cooking of the meal (baking, etc.), stone tools are basic instruments used in various stages to transform such ingredients, though not the only ones. This experimental project aims to reconstruct culinary traditions in prehistoric Europe by means of the functional analysis of grinding stone tools used in the different plant food processing phases.

Our focus is placed on querns made of different raw materials (sedimentary, igneous and metamorphic stones), representing two main size ranges (querns $>30 \mathrm{~cm}$ long, and querns $<30$ cm long), with various surface morphologies, used with different kinematics (back-and-forth reciprocal and circular motion). Rotary querns are not included in the experiments. We are interested in exploring how these variables affect the different ground products. The experimental protocol focuses not only on the process of grinding (Figure 5), but, also, on the methods of manufacture of stone tools (conducted by Antoni Palomo, Figure 6). The grinding toolkits that are replicated in the experiments are representative of the types of grinding tools observed in the archaeological record of the studied areas (for a more detailed presentation see Bofill et al. 2020).

A variety of plant ingredients (cereals, legumes, oilseeds and nuts) were experimentally ground in order to explore the resulting use-wear traces and associated plant micro remains (starches and phytoliths). 


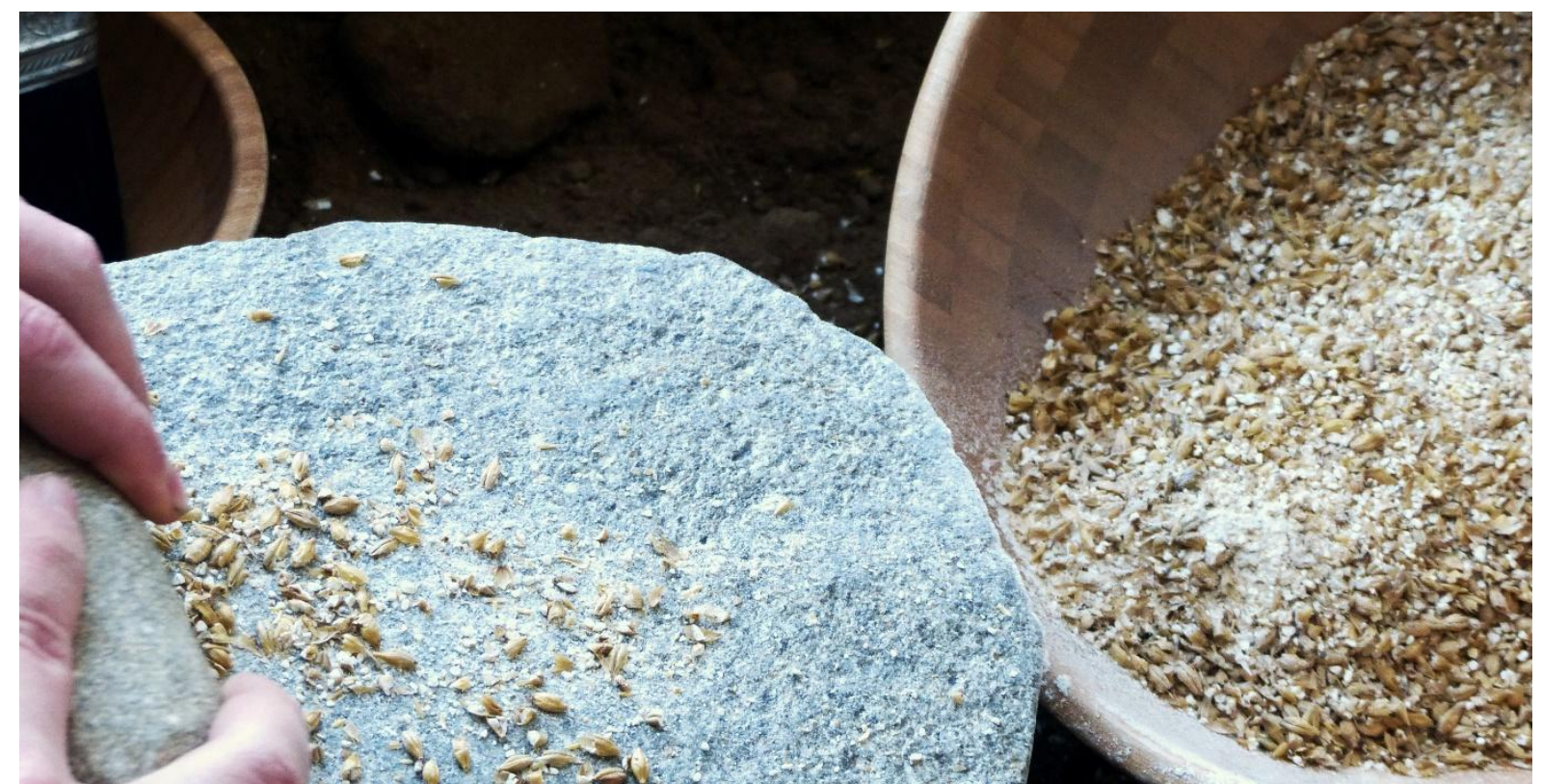

Figure 5. Experimental grinding of malt (after Valamoti 2018, ERC PLANTCULT)

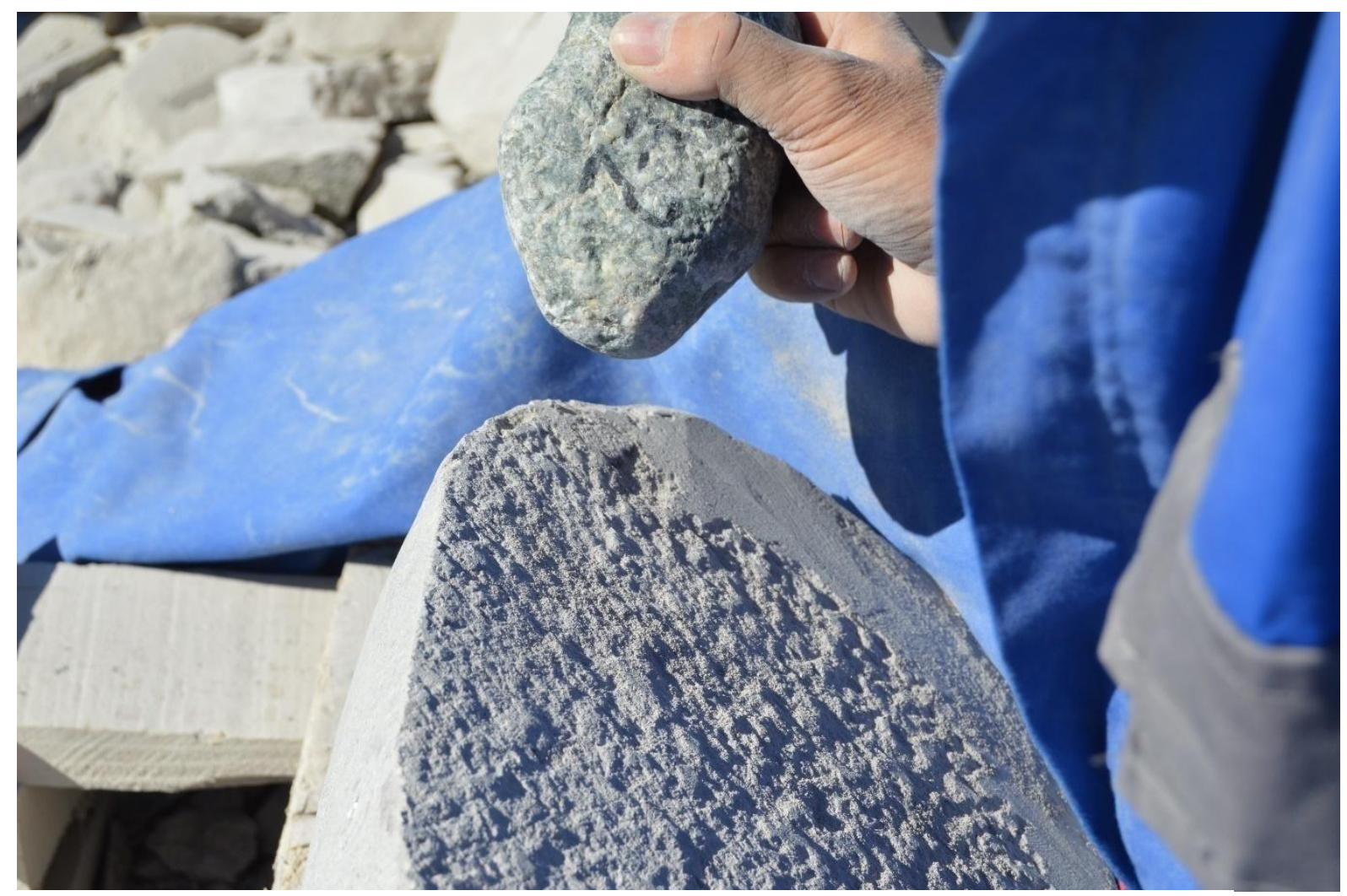

Figure 6. Manufacture of experimental grinding tools: pecking of the use-surface (ERC PLANTCULT).

\subsection{Plant foods}

The corpus of plant macro- and micro-remains (starches and phytoliths) to be examined in the context of our research program is divided into three groups:

a) Actual plant foods and plant ingredients preserved in the archaeobotanical record from key sites

b)Plant micro-remains recovered from archaeological tools

c) Plant micro-remains from experimental tools 
The major focus of this project lies on the actual plant food macro-remains, which consist of processed cereal grain (Figure 7), pulse seed and fruit (grapes), and correspond to different stages of food preparation. Cereal finds, for example, may correspond to pre-cooked cereals like bulgur and some types of trachanas (ground cereals mixed with dairy products) or actual porridge and bread remains; they may also correspond to ground malt, i.e. foodstuffs generated by some form of mechanical alteration of the original, complete form.

Regarding plant micro-remains, PLANTCULT's experimental study focuses on the changes in starch and phytolith morphology as a result of mechanical processing (grinding, pounding, de-husking) and cooking (roasting, baking, boiling). Microbotanical residues have been extracted from experimental tools used to process a variety of plant products (Figure 8). These residues are being analysed to determine the microbotanical assemblage on tools utilized for the processing of multiple plant products and to assess the impact of grinding time and raw material type on phytolith and starch morphology. These comparative experimental data will provide fundamental information for the future analysis of the archaeological ground stone tools.

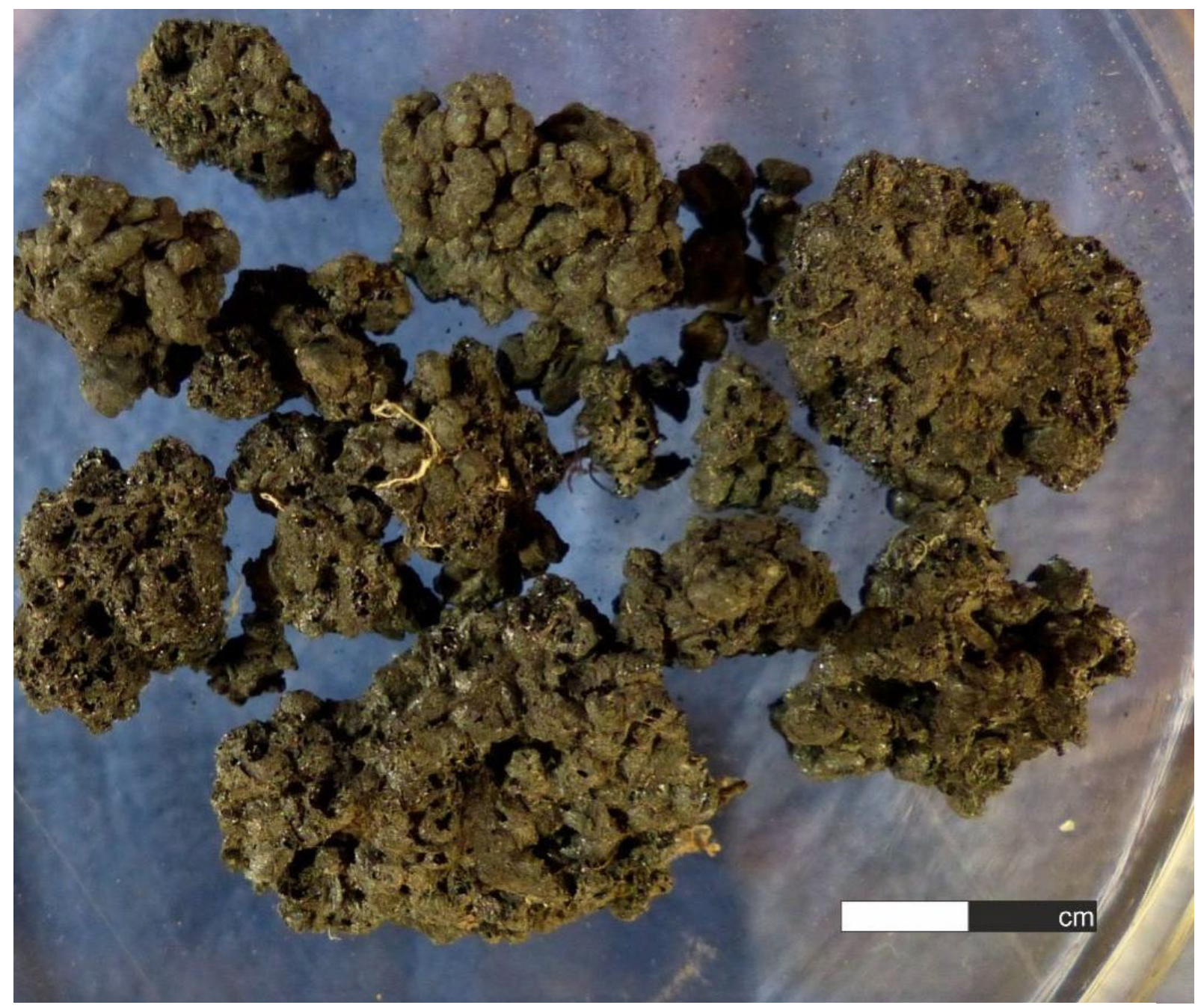

Figure 7. Cereal-based food remains from Archontiko Giannitson (after Valamoti 2018, ERC PLANTCULT). 


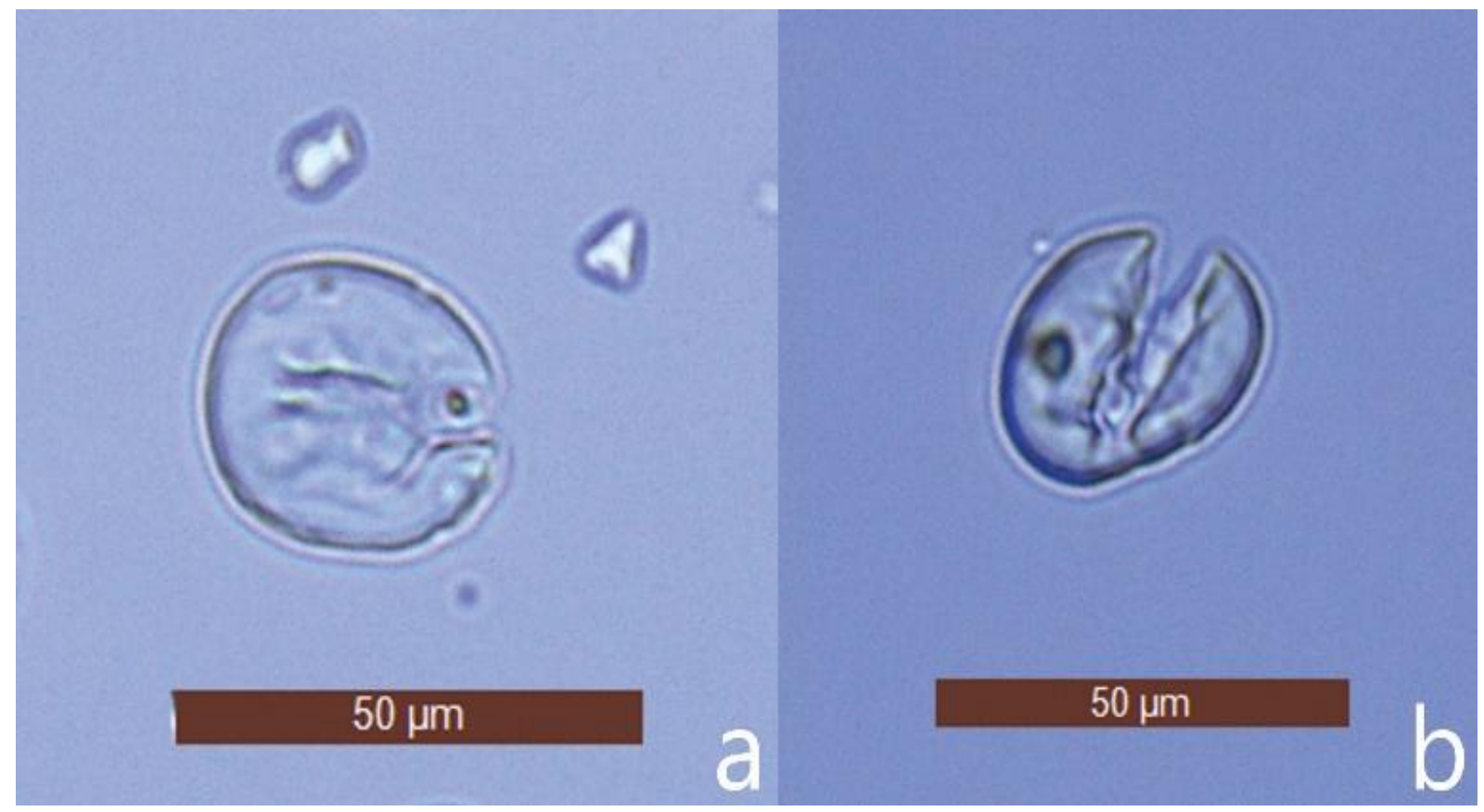

Figure 8. Experimental einkorn (a) and barley (b) starch granules showing cracks induced by grinding (ERC PLANTCULT).

\section{Conclusion}

Our approach is based on the integration of multiple materials (e.g., plant remains, stone tools) and archaeological, ethnographic as well as historical sources, in order to associate the plant foods generated with the related technologies and surrounding culinary traditions. In this respect, each individual research approach constitutes an integral part of the project. In addition to the archaeological case studies, the experimental program will help us generate a methodological tool for interpreting tool functional characteristics in different archaeological contexts, while the ethnographic research will offer us a detailed insight into the cultural polymorphism allowing for comparisons and further thoughts.

\section{Acknowledgements}

The authors wish to thank the following archaeologists for providing ground stone tools for study in the context of project PLANTCULT: Alexander Chohadziev, Areti Chondrogianni-Metoki, Pascal Darcque, Sonia Dimaki, Georgia Karametrou-Mentesidi, Stavros Kotsos, Chaido Koukouli-Chrysanthaki, Dimitra Malamidou, Nikos Merousis, Maria Pappa, Aikaterini Papanthimou, Liana Stefani, Zoi Tsirtsoni, Christina Ziota.

This work has been funded by the European Research Council project "PLANTCULT: Identifying the food cultures of ancient Europe”, under the European Union Horizon 2020 research and innovation program (Grant Agreement No 682529, Consolidator Grant 20162021).

The authors would like to thank the volume editor and two anonymous reviewers for their constructive comments on an earlier version of this paper. 


\section{References}

Abadi-Reiss, Y., \& Schneider, J.S. 2010, Design Theory and Milling Stone Production and Consumption in the Highland Negev Early Bronze Age. In: Techniques and People: anthropological perspectives on technology in the archaeology of the proto-historic and early historic periods in the Southern Levant (Rosen, S.A. \& Roux, V., Eds.), French Institute, Jerusalem: p. 81-98.

Adams, J.L. 1989, Experimental replication of the use of ground stone tools. KIVA, 54(3): 261-271. doi:10.1080/00231940.1989.11758120

Adams, J.L. 1999, Refocusing the role of food grinding tools as correlates for subsistence strategies in the U.S. Southwest. American Antiquity, 64(3): 475-498. doi:10.2307/2694147

Adams, J.L. 2008, Beyond the broken. In: New approaches to old stones: Recent studies of ground stone artifacts (Rowan, Y., \& Ebeling, J., Eds.), Equinox, London: p. 213-229.

Adams, J., Delgado, S., Dubreuil, L., Hamon, C., Plisson, H., \& Risch, R. 2009. Functional analysis of macro-lithic artefacts. In: Non-flint Raw Material Use in Prehistory Old Prejudices and New Direction, $15^{\text {th }}$ Union Internationale des Sciences Préhistoriques et Protohistoriques (UISPP) congress, Lisbon-September 2006 (Sternke, F., Eigeland, L., \& Costa, L., Eds.), BAR International Series Vol 1939, Archeopress, Oxford: p. 43-66.

Akkermans, P.M.M.G., Brüning, M., Hammers, N., Huigens, H., Kruijer, L., Meens, A., Nieuwenhuyse, O., Raat, A., Rogmans, E.F., Slappendel, C., Taipale, S., Tews, S., \& Visser, E. 2012, Burning down the house: the burnt building V6 at Late Neolithic Tell Sabi Abyad, Syria. Analecta Praehistorica Leidensia, 43-44: 307-324.

Alonso, N., Prats, G., Roustanis, T., Tokmakides, P., Valamoti, M. S., 2020, Ethnogrinding Database: A tool to collect and connect worldwide information on ethnological and ethnoarchaeological hand-milling systems. Journal of Lithic Studies, 7(3). doi:10.2218/jls.3095

de Beaune, S. A. 1989, Essai d'une classification typologique des galets et plaquettes utilisés au Paléolithique. Gallia Préhistoire, 31: 27-64. (in French) ("Test of the typological classifications of pebbles and plaquettes used during the Paleolithic"). doi:10.3406/galip.1989.2264

Bofill, M. 2012, Quantitative analysis of use-wear patterns: A functional approach to study grinding stone tools. In: Broadening horizons 3: Conference of young researchers working in the Ancient Near East (Borrell Tena, F., Bouso García, M., Anna Gómez Bach, Tornero Dacasa, C. \& Campos O. V., Eds.), Universitat Autònoma de Barcelona, Barcelona, Servei de Publicacions, Bellaterra: p. 63-84.

Bofill, M. 2015, Inicio y consolidación de las practices agrícolas durante el neolítico en el levanter mediterráneo (septentrional y central): El proceso de molienda y trituración a partir del análisis functional del instrumental macrolítico. Unpublished Ph.D. Thesis, Departament de Prehistòria, Universitat Autònoma de Barcelona, Barcelona, 737 p. (in Spanish) ("The beginning and consolidation of the farming practices during the Neolithic in West Mediterranean (northern and central): The grinding and pounding process through the fuctional analysis of macrolithic tools”) 
Bofill, M., Procopiou, H., Vargiolu, R., \& Zahouani, H. 2013, Use-wear analysis of near eastern prehistoric grinding stones. In: Regards croisés sur les outils liés au travail des végétaux: An interdisciplinary focus on plant-working tools, XXXIII rencontres internationales d'archéologie et d'histoire d'Antibes (Anderson, P.C., Cheval, C. \& Durand, A., Eds.), Association pour la promotion et la diffusion des connaissances archéologiques (APDCA), Antibes: p. 225-242.

Bofill, M., Chondrou, D., Palomo, A., Procopiou, H., \& Valamoti, S.M. 2020, Processing plants for food: Experimental grinding within the ERC-project PLANTCULT. Journal of Lithic Studies, vol. 7(3). doi:10.2218/jls.3079

Capparelli, A., Valamoti, S.M., \& Wollstonecroft, M.M. 2011, After the harvest: investigating the role of food processing in past human societies. Archaeological and Anthropological Sciences, 3(1): 1-5. doi:10.1007/s12520-011-0063-2

David, N. 1998, The ethnoarchaeology of grinding at Sukur, Adamawa state, Nigeria. African Review, 15(1): 13-63. doi:10.21474/ijar01/739

Delgado-Raack, S. 2008, Prácticas económicas y gestión social de recursos (macro)lìticos en la Prehistoria Reciente (III-I Milenio AC) del Mediterráneo Occidental. Unpublished Ph.D. Thesis, Universitat Autònoma de Barcelona, Bellaterra, 266 p. (in Spanish) ("Economic Practices and Social Management of (Macro)lithic Resources of the Late Prehistory (III-I millenia BCE) in the Western Mediterranean”)

Delgado-Raack, S., Gómez-Gras, D., \& Risch, R. 2009, The mechanical properties of macrolithic artifacts: a methodological background for functional analysis. Journal of Archaeological Science, 36(9): 1823-1831. doi:10.1016/j.jas.2009.03.033

Del Pilar Babot, M., \& Apella, M.C. 2003, Maize and bone. Residues of grinding in northwestern Argentina. Archaeometry, 45: 121-132. doi:10.1111/1475-4754.00099

Dubreuil, L. 2002, Étude fonctionnelle des outils de broyage natoufiens: nouvelles perspectives sur l'émergence de l'agriculture au Proche-Orient. Unpublished Ph.D. Thesis, Université de Bordeaux 1, Bordeaux, 469 p. (in French) ("Functional studies of the natufian grinding tools: new perspectives on the emergence of agriculture in the Near East”)

Dubreuil, L. 2004, Long-term trends in Natufian subsistence: A use-wear analysis of ground stone tools. Journal of Archaeological Science, 31: 1613-1629. doi:10.1016/j.jas.2004.04.003

Dubreuil, L. 2008, Mortar versus grinding-slabs and the neolithization process in the Near East. In: "Prehistoric Technology" 40 years later: Functional studies and the Russian legacy (Longo, L., \& Skakun, N. Eds.), Museo Civico di Verona \& Università degli Studi di Verona, Verona: p. 169-177.

Dubreuil, L., Savage, D., Delgado-Raack, S., Plisson, H., Stephenson, B., \& De la Torre, I. 2015, Current analytical framework studies of use-wear on ground stone tools. In: Usewear and residue analysis in archaeology. Manuals in archaeological method, theory and technique (Marreiros, J.M., Gibaja Bao, J.F., \& Ferreira Bicho, N., Eds.), Springer International Publishing, New York: p. 105-158.

Dubreuil, L., \& Nadel, D. 2015, The development of plant food processing in the Levant: insights from use-wear analysis of Early Epipalaeolithic ground stone tools. Philosophical Transactions of Royal Society Publishing, 370: 20140357. doi:10.1098/rstb.2014.0357 
Ebeling, J.R., \& Rowan, Y.M. 2004, The Archaeology of the Daily Grind: Ground Stone Tools and Food Production in the Southern Levant. Near Eastern Archaeology, 67(2): 108-117. doi:10.2307/4132366

Gast, M. 1968, Alimentation des populations de l'Ahaggar: étude ethnographique. Arts et métiers graphiques, Paris, 457 p. (in French) ("Food habits of the population in Ahaggar: an ethnographic study”)

Gosden, C., \& Marshall, Y. 1999, The cultural biography of objects. World Archaeology, 31(2): 169-178. doi:10.1080/00438243.1999.9980439

Gould, R. 1968, Living archaeology: the Ngaratatjara of Western Australia. Southwestern Journal of Anthropology, 24(2): 101-122. doi:10.1086/soutjanth.24.2.3629417

Hamon, C. 2006, Broyage et abrasion au Néolithique ancien: Caractérisation technique et fonctionnelle des outillages en grès du Bassin parisien. BAR International Series 1551, Oxford, 342 p. (in French) ("Grinding and abrasion in Early Neolithic: Technical and functional characterisation of sandstone tools in the Paris basin")

Hamon, C. 2008, Functional analysis of stone grinding and polishing tools from the earliest Neolithic of north-western Europe. Journal of Archaeological Science, 35(6): 15021520. doi:10.1016/j.jas.2007.10.017

Hamon, C., \& Le Gall, V. 2013, Millet and sauce: The uses and functions of querns among the Minyanka (Mali). Journal of Anthropological Archaeology, 32: 109-121. doi:10.1016/j.jaa.2012.12.002

Hardy, K., Buckley, S., Collins, M.J., Estalrrich, A., Brothwell, D., Copeland, L., GarcíaTabernero, A., García-Vargas, S., Rasilla, M., Lalueza-Fox, C., Huguet, R., Bastir, M., Santamaría, D., Madella, M., Wilson, J., Fernández Cortes, A., \& Rosas, Á. 2012, Neanderthal medics? Evidence for food, cooking, and medicinal plants entrapped in dental calculus. Naturwissenschaften, 99: 617-626. doi:10.1007/s00114-012-0942-0

Hayes, E. H., Cnuts, D., Lepers, C., \& Rots, V. 2017 Learning from blind tests: Determining the function of experimental grinding stones through use-wear and residue analysis. Journal of Archaeological Science: Reports, 11: 245-260. doi:10.1016/j.jasrep.2016.12.001

Hodder, I. 2012, Entangled: An archaeology of the relationships between humans and things. Wiley-Blackwell, Chichester, 245 p.

Horsfall, G.A. 1987, Design theory and grinding stones. In: Lithic studies among the contemporary highland Maya (Hayden, B., Ed.), The University of Arizona Press, Tucson: p. 332-377.

Hoskins, J. 1998, Biographical objects: how things tell the stories of people's lives. Routledge, New York, 213 p.

Hoskins, J. 2006, Agency, biography and objects. In: Handbook of Material Culture (Tilley, C., Keane, W., Küchler, S., Rowlands, M., \& Spyer, P., Eds.), Sage Publications, London: p. 74-84.

Kanfani-Zahar, A. 1994, Mune. La conservation alimentaire traditionnelle au Liban. Éditions de la Maison des Sciences de l'homme, Paris, 266 p. (in French) ("Mune. The traditional conservation of food in Liban”). 
Kopytoff, I. 1986, The cultural biography of things: commoditization as process. In: The social life of things: commodities in cultural perspective (Appadurai, A., Ed.), Cambridge University Press, Cambridge: p. 64-91.

Kraybill, N. 1977, Pre-Agricultural tools for the preparation of foods in the Old World. In: Origins of agriculture (Reed, C.A., Ed.), Mouton Publishers, The Hague \& Paris: p. 485-521.

McCarthy, F.D. 1941, Aboriginal grinding stones and mortars. The Australian Museum Magazine, 7: 329-333.

McCarthy, F.D. 1976, Australian aboriginal stone implements. The Australian Museum Trust, Sydney, (2nd ed.), 107 p.

Mensanch, M., Risch, R., \& Soldevilla, J.A. 2002, Las tecnologias del procesado de cereal en el sudeste de la peninsula Iberica durante el III y el II milenio A.N.E. In: Moudre et Broyer. L'interprétation fonctionnelle de l'outillage de mouture et de broyage dans la Préhistoire et l'Antiquité. I. Méthodes (Procopiou, H., \& Treuil, R., Eds.), Comité des Travaux Historiques et Scientifiques (CTHS), Paris: p. 81-110. (in Spanish) ("The technology of cereal processing in Southeast Iberian Peninsula during the III and II millenia BP”)

Meurers-Balke, J., \& Lüning, J. 1992, Some aspects and experiments concerning the processing of the glume wheat. In: Préhistoire de l'agriculture, nouvelles approches expérimentales et ethnographiques (Anderson, P.C., Ed.), Monographie du Centre de recherches archéologiques (CRA) 6, Paris: p. 341-362.

Mildwaters, J. \& Clarkson, C. 2018, The efficiency of Australian grindstones for processing seed: A quantitative experiment using reproduction implements and controlling for morphometric variation and grinding techniques. Journal of Archaeological Science: Reports 17: 7-18. doi:10.1016/j.jasrep.2017.10.036

Molloy, B., Day, J., Bridgford, S., Isaakidou, V., Nodarou, E., Kotzamani, G., Milić, M., Carter, T., Westlake, P., Klontza-Jaklova, V., Larsson, E., \& Hayden B.J. 2014, Life and death of a Bronze Age house: Excavation of Early Minoan I levels at Priniatikos Pyrgos. American Journal of Archaeology, 118: 307-358. doi:10.3764/aja.118.2.0307

Moritz L. A. 1958, Grain-mills and flour in classical Antiquity. Clarendon Press, Oxford, 230 p.

Naveh, D. 1996, Patterns of activity in the pottery Neolithic sites of Nahal Zehora II based on ground stone tools and grain distribution. Proceedings of the XIII congress of the International Union of Prehistoric and Protohistoric Sciences Vol. 3, (Peretto, C., \& Giunchi, C. Eds.) 8-14 September 1996, Forli: p. 469-474.

Nelson, M.C., \& Lippmeier, H. 1993, Grinding-tool design as conditioned by land-use pattern. American Antiquity, 58(2): 286-305. doi:10.2307/281971

Nierlé, M.C. 1983, Mureybet et Cheikh Hassan (Syrie): Outillage de mouture et de broyage (9ème et 8ème millénaires). Cahiers de l' Euphrate 3: 177-216. (in French) ("Mureybet and Cheikh Hassan (Syria): Milling and grinding tools ( $9^{\text {th }}$ and $8^{\text {th }}$ millennia”))

Nierlé, M. C. 2008, L’outillage de mouture et de broyage. In: Le site néolithique de Tell Mureybet (Syrie du Nord), Vol. II (Ibáñez, J. J. Ed.), BAR International Series Vol. 1843, Archaeopress, Oxford: p. 405. (in French) (“Grinding and milling tools”) 
Nixon-Darcus, L. 2014, The cultural context of food grinding equipment in Northern Ethiopia: An ethnoarchaeological approach. Unpublished M.A. Thesis, Simon Fraser University, $343 \mathrm{p}$.

Power, R.C., Rosen, A.M., \& Nadel, D. 2016, Phytolith evidence of the use of plants as food by Late Natufians at Raqefet Cave. In: Wild harvest: plants in the Hominin and PreAgrarian human worlds (Hardy, K., \& Kubiak-Martens, L., Eds.), Oxbow, Oxford: p. 191-214.

Procopiou, H. 1998, L'outillage de mouture et de broyage en Crète Minoenne. Unpublished Ph.D. Thesis, Université de Paris I, Panthéon-Sorbonne, 442 p. (in French) ("The milling and grinding tools of Minoan Crete")

Procopiou, H. 2003, Les techniques de décorticage dans le monde égéen: étude ethnoarchéologique dans les Cyclades. In: Le traitement des récoltes: un regard sur la diversité, du Néolithique au Présent. XXIIIe Rencontres Internationales d'Archéologie et d'Histoire d'Antibes, Antibes, (Anderson, P.C., Cummings, L.C., Schippers, T.K., \& Simonel B., Eds.) Association pour la promotion et la diffusion des connaissances archéologiques (APDCA), Antibes: p. 115-136. (in French) ("The techniques of shelling in the Aegean world: an ethnoarchaelogical study in the Cyclades”)

Procopiou, H. 2004, Le broyage des matières minérales: l'apport de la tribologie à l'identification de la transformation des matières minérals. Dossiers D' Archéologie, 290: 58-61. (in French) ("The grinding of minerals: the contribution of tribology in the identification of the transformation of minerals")

Revedin, A., Aranguren, B., Becattini, R., Longo, L., Marconi, E., Lippi, M. M., Skakun, N., Sinitsyn, A., Spiridonova, E., \& Svoboda, J. 2010, Thirty thousand-year-old evidence of plant food processing. Proceedings of the National Academy of Sciences of the United States of America, 107(44): 18815-18819. doi:10.1073/pnas.1006993107

Rosenberg, D. 2013, Not 'Just Another Brick in the Wall?' The symbolism of ground stone tools in Natufian and Early Neolithic southern levantine constructions. Cambridge Archaeological Journal, 23(2): 185-201. doi:10.1017/s095977431300022x

Roux, V. 1985, Le matériel de broyage. Étude ethnoarchéologique à Tichitt (R.I.) Mauritanie. Edition Recherches sur les civilisations, mémoire no 58, Paris, 111 p. (in French) ("The material of milling. Ethnoarchaeological study in Tichitt (I.R.), Mauritania”).

Rowan, Y.M., \& Ebeling, J.R. 2008, Introduction: The potential of ground stone studies. In: New Approaches to Old Stones. Recent studies of ground stone artifacts (Rowan, Y.M., \& Ebeling, J.R. Eds.), Equinox, London: p. 1-15

Runnels, C. 1981, A diachronic study and economic analysis of millstones from the Argolid. Upublished Ph.D. Thesis, Indiana University, Bloomington, 403 p.

Searcy, M.T. 2011, The life-giving stone: Ethnoarchaeology of Maya metates. The University of Arizona Press, Tucson, 192 p.

Schön, W., \& Holter, U. 1990, Grinding implements from the neolithic and recent times in desert areas in Egypt and Sudan. Beiträge zur Allgemeinen und Vergleichenden Archäologie, 9-10: 359-379.

Schneider, J.S. 2002, Milling tool design, stone textures, and function. In: Moudre et Broyer, L’interprétation fonctionnelle de l'outillage de mouture et de broyage dans la Préhistoire et l’Antiquité. I. Méthodes (Procopiou, H., \& Treuil, R., Eds.), Comité des Travaux Historiques et Scientifiques (CTHS), Paris: p. 31-53. 
Schroth, A.B. 1996, An Ethnographic Review of Grinding, Pounding, Pulverizing, and Smoothing with Stones. Pacific Coast Archaeological Society Quarterly, 32(4): 55-75.

Shoumacker, A. 1993, Apports de la technologie et de la pétrographie pour la caractérisation des meules. In: Traces et fonction, les gestes retrouvés. Actes Du Colloque International de Liège, 8-10 Décembre 1990, Valbonne, (Anderson, P.C., Beyries, S., Otte, M., \& Plisson, H., Eds.), Centre de Recherches Archéologiques du Centre national de la recherche scientifique (CNRS) \& Etudes et Recherches Archéologiques de l’Université de Liège: p. 165-76 (in French) ("Contribution of technology and petrography for the characterization of mills”)

Stahl, A.B. 1984, Hominid dietary selection before fire. Current Anthropology, 25: 151-168. doi:/10.1086/203106

Stahl, A.B. 1989, Plant-food processing: Implications for dietary quality. In: Foraging and farming: the evolution of plant exploitation (Harris, D.R., \& Hillman, G.C., Eds.), Unwin Hyman, London: p. 171-194.

Stroulia, A. 2010, Flexible stones. Ground stone tools from Franchthi Cave. Fascicle 14, Excavations at Franchthi Cave, Greece, Bloomington, Indiana University Press, Indianapolis, $242 \mathrm{p}$.

Stroulia, A., \& Chondrou, D. 2013, Destroying the means of production: The case of ground stone tools from Kremasti-Kilada, Greece. In: Destruction: Archaeological, Philological and Historical Perspectives (Driessen, J. Ed.), Presses Universitaires de Louvain, Louvain, Belgium: p. 109-131.

Stroulia, A., Dubreuil, L., Robitaille, J., \& Nelson, K. 2017. Salt, sand, and saddles: Exploring an intriguing work face configuration among grinding tools. Ethnoarchaeology, 9(2): 119-145. doi:10.1080/19442890.2017.1364053

Tsoraki, C. 2008, Neolithic society in Northern Greece: the evidence of ground stone artefacts. Unpublished Ph.D. Thesis, University of Sheffield, 383 p.

Valamoti, S.M. 2011, Ground cereal food preparations from Greece: the prehistory and modern survival of traditional Mediterranean 'fast foods'. Archaeological and Anthropological Sciences, 3(1): 19-39. doi:10.1007/s12520-011-0058-z

Valamoti, S.M. 2017, Culinary landscapes and identity in prehistoric Greece: An archaeobotanical exploration. In: Balkan dialogues, negotiating identity between Prehistory and the Present (Gori, M., \& Ivanova, M., Eds.), Routledge, Oxford: p.169194.

Valamoti, S.M. 2018, Brewing beer in wine country? First archaeobotanical indications for beer making in Early and Middle Bronze Age Greece, Vegetation History and Archaeobotany, 27: 611-625. doi:10.1007/s00334-017-0661-8

Valamoti, S.M., Chondrou, D., \& Papadopoulou, L. 2013, Plant food processing and ground stone equipment in prehistoric Greece: An experimental investigation using seeds of einkorn and grass-pea. In: Regards croisés sur les outils liés au travail des végétaux: An interdisciplinary focus on plant-working tools, XXXIII rencontres internationales d'archéologie et d'histoire d'Antibes (Anderson, P.C., Cheval, C. \& Durand, A., Eds.), Association pour la promotion et la diffusion des connaissances archéologiques (APDCA), Antibes: 169-187. 
Valamoti, S.M., Jacomet, S., Stika, H.P., \& Heiss, A.G. 2017, The PLANTCULT Project: identifying the plant food cultures of ancient Europe. Antiquity, 91(358): e9. doi:10.15184/aqy.2017.130

Wright, K.I. 1991, The origins and development of ground stone assemblages in Late Pleistocene Southwest Asia. Paléorient 17(1): 19-45. doi:10.3406/paleo.1991.4537

Wright, K.I. 1994, Ground-stone tools and hunter-gatherer subsistence in Southwest Asia: Implications for the transition to farming. American Antiquity, 59(2): 238-263. doi:10.2307/281929

Wright, K.I. 2000, The social origins of cooking and dining in early villages in Western Asia. Proceeding of Prehistoric Society, 66: 89-121. doi:10.1017/s0079497x0000178x

Wright, K.I. 2014, Domestication and inequality? Households, corporate groups and food processing tools at Neolithic Çatalhöyük. Journal of Anthropological Archaeology, 33: 1-33. doi:10.1016/j.jaa.2013.09.007

Yen, D.E. 1989, The domestication of environment. In: Foraging and farming: the evolution of plant exploitation (Harris, D.R., \& Hillman, G.C., Eds.), Unwin Hyman, London: p. 55-75.

Zimmerman, A. 1988, Steine. In: Der bandkeramische Siedlungsplatz Langweiler 8 (Boelicke, U., Brandt, D.V. Lüning, J., Stehli, P. Zimmerman, A., Eds.), Rheinische Ausgrabungen Vol. 28, Rheinland Verlag, Cologne: p. 569-787 (in German) (“Stone”). 